\title{
Reservoir characterisation using process-response simulations: the Lower Cretaceous Rijn Field, West Netherlands Basin
}

\author{
L.J.H. Alberts ${ }^{1,3}$, C.R. Geel ${ }^{1}$ \& J.J. Klasen ${ }^{2}$ \\ ${ }^{1}$ Delft University of'Technology, Department of Applied Earth Sciences, Mijnbouwstraat \\ 120, 2628 RX Delft, The Netherlands \\ ${ }^{2}$ BP Nederland Energie B.V., Bezuidenhoutseweg 74, 2594 AW Den Haag, The Nether- \\ lands \\ ${ }^{3}$ corresponding author; e-mail: 1.j.h.alberts@citg.tudelft.nl
}

Manuscript submitted: December 2001; accepted: March 2003

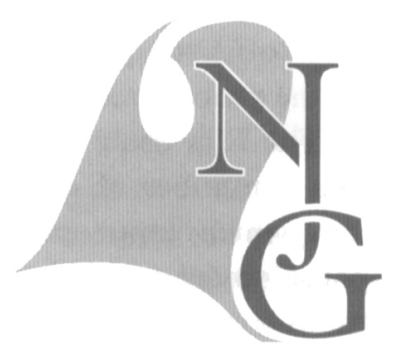

\begin{abstract}
Petroleum geologists always need to deal with large gaps in data resolution and coverage during reservoir characterisation. Seismic data show only large geological structures, whereas small-scale structures and reservoir properties can be observed only at well locations. In the area between wells, these properties are often estimated by means of geostatistics. Numerical simulation of sedimentary processes offers an alternative method to predict these properties and can improve the understanding of the controls on reservoir heterogeneity. Although this kind of modelling is widely used on basin scale in exploration geology, its application on field scale in production geology is virtually non-existent. We have assessed whether the recent developments in numerical modelling can also aid petroleum geologists in the interpretation of the reservoir geology.

Seismic data, well data and a process-response model for coastal environments were used to characterise the Lower Cretaceous oil-bearing Rijn Field. Interpretation of seismic and well data led to a definition of the structural setting and the depositional model of the Rijn Member in the area. From the sedimentological interpretation the sea-level history could be estimated, which is the one of the most important input parameters for the process-response model.

Application of the process-response simulator to the Rijn Field resulted in approval of the depositional model. The output was presented in a 2-dimensional north-south profile, which corresponds very well to the well logs along this section. The results demonstrate that numerical simulations of geological processes can be very useful as a tool to explore many likely geological scenarios. While it cannot be used to supply a unique solution in many cases, it forms a helpful guide during reservoir characterisation to find an optimal scenario of the controls on deposition of the Rijn Member, which contributes to the understanding of the inter-well reservoir heterogeneity.
\end{abstract}

Keywords: reservoir characterisation, process-response modelling, Rijn Field, shallow marine/shoreface environment, sequence stratigraphy, West Netherlands Basin

\section{Introduction}

The geological characterisation of hydrocarbon fields is often very difficult due to the sparse or even absent data in-between the wells. Especially in offshore fields the average distance between wells can be more than $1000 \mathrm{~m}$, resulting in considerable data gaps. Not surprisingly, reserve estimates and production forecasts are often notoriously wrong (Dromgoole \& Spears,
1997), part of which can be attributed to a poor geological reservoir model. While geostatistical stochastic models are now employed routinely by the major oil companies (Dubrule \& Damsleth, 2001), these models mainly aim to quantify uncertainty without enhancing the geological understanding of the reservoir. There seems to be a clear need for reservoir characterisation tools based on geological principles.

Recent advances in stratigraphic simulation model- 
ling seem to hold promises for reservoir characterisation (Watney et al., 1999; Tetzlaff \& Pride, 2001). These numerical models comprise already most depositional environments (cf. Syvitski \& Hutton, 2001; Granjeon \& Joseph, 1999). In this paper we focus our attention on BARSIM (Storms et al., 2002; Storms, 2002), which simulates the processes and deposits of coastal environments. This model is able to predict sediment distribution and coastal evolution using basic geological inputs such as sea-level fluctuations, sediment supply, and the initial coastal topography. It was tested successfully on some present-day coasts.

The Rijn Field, a Lower Cretaceous oil field in the Dutch offshore, provides an excellent opportunity to test the process-response model on a subsurface data set. The Rijn Field data set includes ample well log data, a number of cores, and a 3D seismic survey from which input parameters for the process-response model could be derived. Furthermore, its sediments were deposited in a marine to coastal environment in the West Netherlands Basin for which the general paleotopographic setting, sediment distribution, and sea-level history are fairly well documented (Den Hartog Jager, 1996).

In the first part of this paper, the regional geology and sedimentology of the Rijn Member will be described. This is followed by a short summary of the seismic interpretation, which is used to extract the paleotopography of the area. Subsequently, we describe the depositional history of the Rijn Member. In the last part of the paper, the process-response model will be explained briefly and the results of the simulations will be discussed.

\section{The Rijn Field}

The Rijn Field is located in block P-15 about 40 kilometres off the coast of The Hague (Fig. 1). The field was discovered in 1982 and is operated by BP Nederland Energie B.V., part of the BP Amoco Group.

The field has been producing oil from the Rijn Member of the Lower Cretaceous Rijnland Group (at approximately 2000-m sub-sea) for over fifteen years. The Rijn Member was deposited in a coastal environment during the Hauterivian in the offshore part of the West Netherlands Basin, and unconformably overlies Triassic and Jurassic formations. The Rijn Field shows many structural and sedimentary similarities to other fields in the region, like the Logger Field in the Broad Fourteens Basin (Goh, 1996) and the

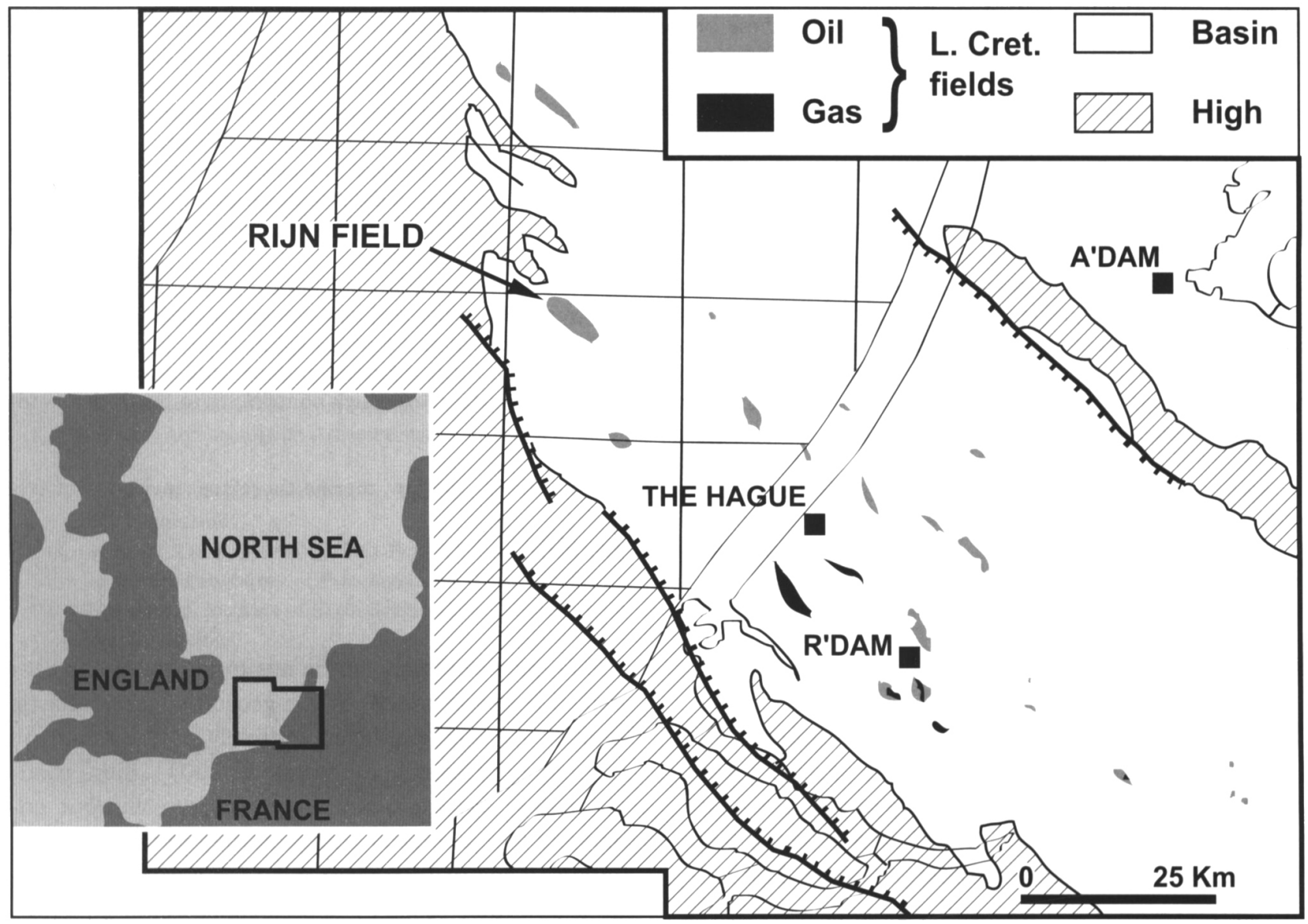

Fig. 1. Map of the Lower Cretaceous West Netherlands Basin and the location of the Rijn Field. (Modified from Den Hartog Jager, 1996). 
Wassenaar and Pijnacker Fields in the onshore part of the West Netherlands Basin (Racero-Baena \& Drake, 1996). Therefore, we first give a short overview of the regional geology of the West Netherlands Basin.

\section{Regional Geology}

The Early Cretaceous NW-SE oriented West Netherlands Basin is surrounded by the London Brabant Massif to the south, the Winterton High to the west and the Zandvoort Ridge and IJmuiden High to the north separate it from the Broad Fourteens Basin. Towards the Southeast the basin borders the Roer Valley Graben.

Although the basin was already present during Triassic times (Van Adrichem Boogaert \& Kouwe, 1993), its morphology became more pronounced after severe extensional faulting initiated during the Middle Jurassic. This period of faulting continued to the Early Cretaceous and is associated with crustal extension across the North Sea Graben system (Bodenhausen \& Ott, 1981; Van Wijhe, 1987).

Thermal doming of the area resulted in tilting of the fault blocks and coincided with a sharp eustatic lowering of the sea level (Ziegler, 1982). Erosion of the exposed formations at the crests of the blocks and deposition of fluvial sediments of the Delfland Group in the valleys took place during the Late Jurassic. It created a partially unconformable boundary between Jurassic and Cretaceous sediments in the West Netherlands Basin (Den Hartog Jager, 1996). This unconformity will be further referred to as the Hils Unconformity, a name locally used at BP.

Post-rift subsidence during the Early Cretaceous allowed a stepwise ingression of the sea from the north. This rise of sea level involved the deposition of transgressive basal sands and coastal barrier sands along the margins of the basin (Bodenhausen \& Ott, 1981; Den Hartog Jager, 1996), which form the main oil reservoirs of the West Netherlands Basin (RaceroBaena \& Drake, 1996). A fully marine environment developed under conditions of persistent relative sea level rise, in which a thick package of marine shales was deposited, followed by a thick interval of carbonates of the Chalk Group at the end of the Cretaceous (Van Adrichem Boogaert \& Kouwe, 1993).

The basin was inverted during two main phases of uplift: the Sub-Hercynian and Laramide compressional stages of Alpine deformation in the Late Cretaceous and Early Tertiary (Van Wijhe, 1987; Dronkers \& Mrozek, 1991; Gras \& Geluk, 1999). This period is associated with reactivation and reversal of normal rift-faults and wrench deformations. The tectonic inversion was responsible for the formation of the anti- clinal structures that nowadays form the most common trap-type in the West Netherlands Basin above the Hils Unconformity (De Jager et al., 1996; RaceroBaena \& Drake, 1996).

\section{Sedimentology}

Little has been published on the sedimentology of the Rijn Field and its surroundings. The Rijn Member is mentioned in the stratigraphic nomenclature of the Netherlands by Van Adrichem Boogaert \& Kouwe (1993) as a more distal lateral equivalent of the Rijswijk Member. The latter consists mainly of material reworked during a transgression (Den Hartog Jager, 1996).

Cores recovered from the Rijn Field show a pervasively bioturbated sandstone sequence in which virtually no primary sedimentary structures are preserved Identified ichnospecies belong mostly to the Cruziana

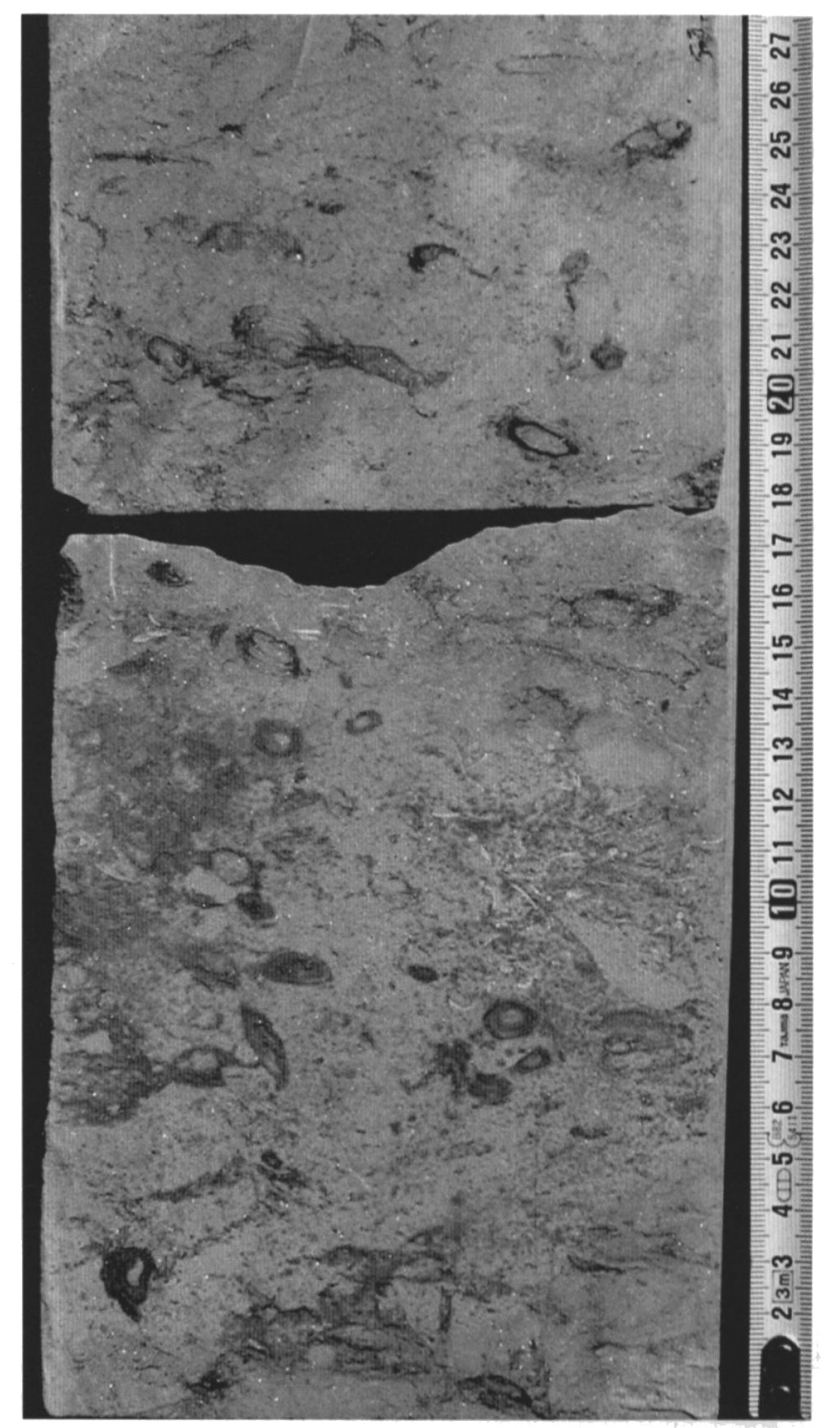

Fig. 2. Core photograph of the Rijn Member. Bioturbated very fine sand with abundant $A$ sterosoma. Well B-1, depth $1980.8 \mathrm{~m}$. 
ichnofacies association (Pemberton et al, 1992) and include a.o. Chondrites, Teichnichnus, Zoophycos, Asterosoma (Fig. 2), Planolites, and Thalassinoides. Near the top of the Rijn Member an occasional Ophiomorpha can be found. Coal fragments and plant remains are abundantly present. Grain size ranges from very fine to medium sand, which correlates very well with the gamma-ray logs (see below). The combination of ichnofacies, plant remains, and grain size indicates a lower shoreface depositional environment.

Two characteristic types of gamma-ray logs can be distinguished in the Rijn Field (Fig. 3) based on differences in the lower part of the Rijn Member. The Type $1 \mathrm{log}$, occurring in the northern wells, has low gamma-ray readings, whereas Type 2 , occurring in the southern wells, has many high gamma-ray peaks.

On the basis of grain-size differences and gammaray log patterns the Rijn Member was subdivided into five units, labelled A through $\mathrm{E}$ from top to bottom. Each unit represents a sub-environment within the lower shoreface setting, which is strongly related to the regional sea-level curve (cf. Den Hartog Jager, 1996). Unit $E$ consists of a basal transgressive sand that shows large variations in thickness. Unit D represents the most seaward environment. Especially in the southern part of the field it contains substantial amounts of shale (Fig. 3, Type $2 \log$ ). Units $C$ through A represent a prograding shoreface, as testified by the coarsening-upward pattern of the gamma-ray logs.

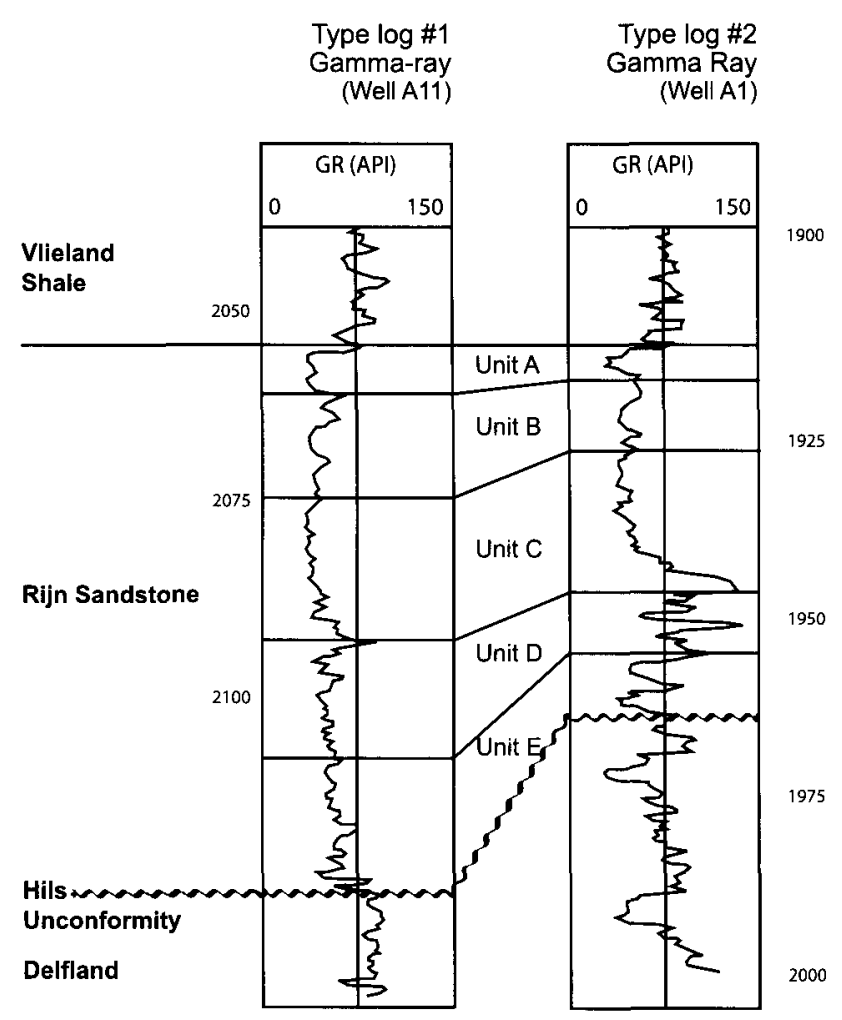

Fig. 3. Gamma-ray type logs for the Rijn Field. Left: Type-1 log, with low Gamma-ray readings in the lower part of the Rijn Member; Right: Type-2 log, with high Gamma-ray reading in the lower part of the Rijn Member.
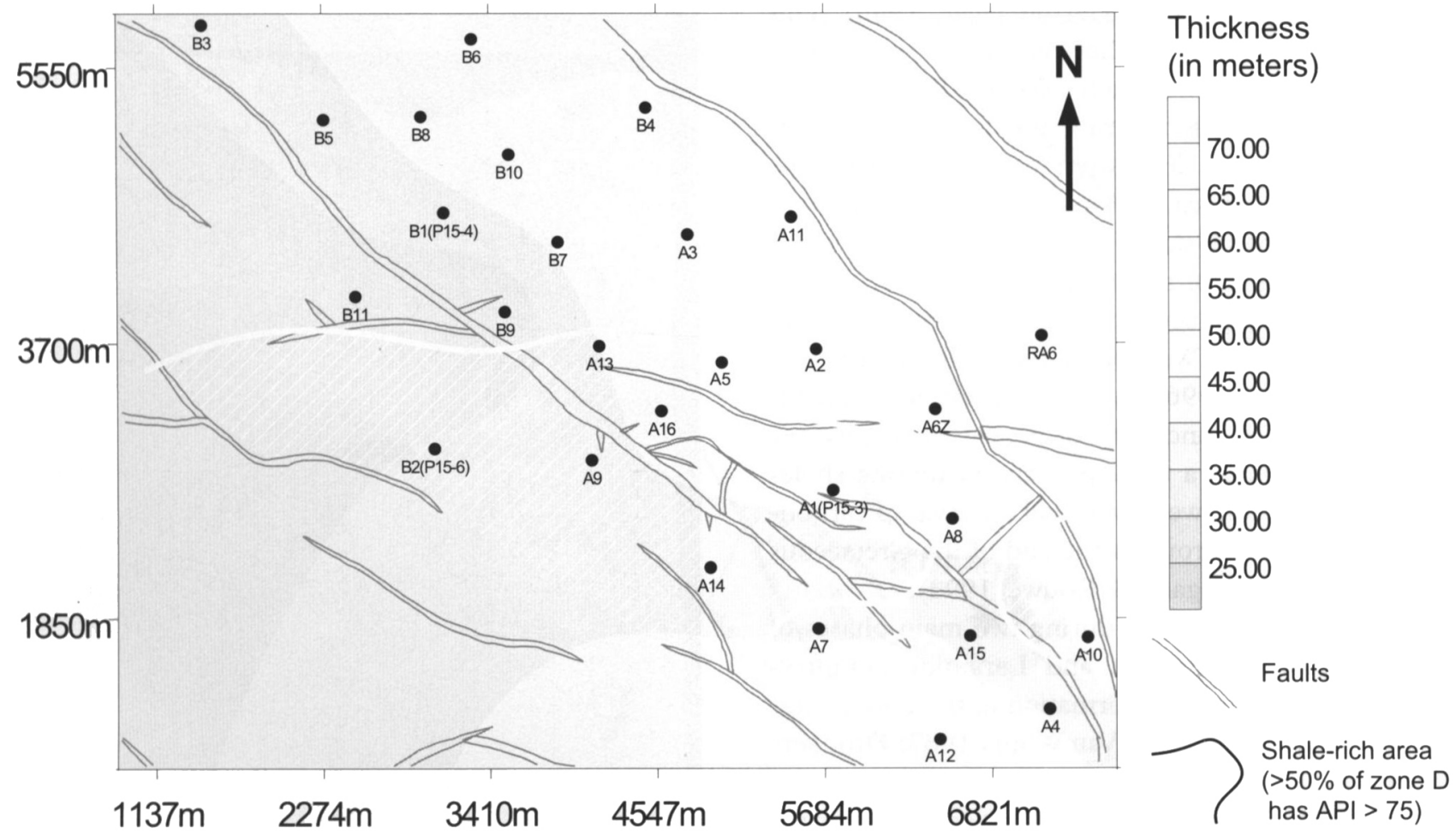

Fig. 4. Isochore map of the Rijn Member. The faults and well locations are shown as reference. The shaded area indicates the region where the lower part of the member contains many shale intercalations. 
The Rijn Member shows a large variation in thickness (Fig. 4). It attains its largest thickness of over 70 $\mathrm{m}$ in the northeastern wells, and there is a gradual decrease to less than $30 \mathrm{~m}$. toward the Southwest. The general trend in thickness variation matches the main structural trend.

Type-2 logs, with a shaly D unit, occur exclusively in the southern part of the field (Fig. 4). The transition from a sandy to a shaly $\mathrm{D}$ unit takes place over a relatively short distance of about $500 \mathrm{~m}$, which makes the $\log$ correlations along N-S cross sections difficult (Fig.5). This transition coincides with a number of E$\mathrm{W}$ trending faults, taken to imply that basement topography due to faulting must have played an important role in the deposition of the Rijn Member.

\section{Paleotopography of the Rijn Field Area}

Before the depositional model can be derived, the original topographical setting must be known. The

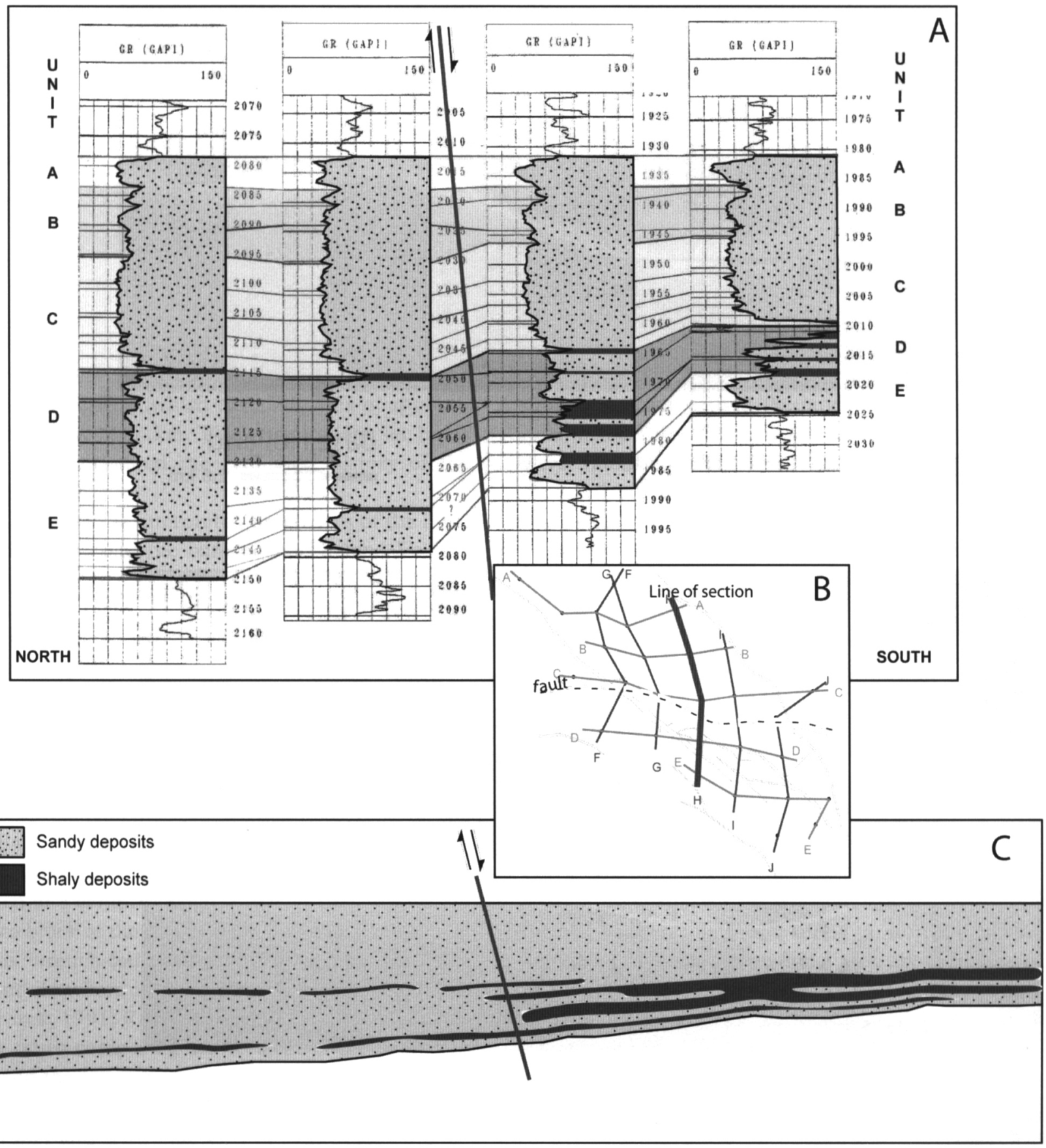

Fig. 5. Comparison of a well correlation panel by Maartense (1999) in Fig. A, and the same section from a stochastic reservoir modelling realisation in Fig. C. The shales in brown and the sands in yellow show reasonable agreement in both sections, but further reservoir heterogeneity must be geostatistically interpolated in the stochastic modelling program. The location of the section is shown in Fig. B. 
Late Cretaceous and Early Tertiary structural deformations dominate the current geological appearance of the area. For the identification of the faulted structures, the available seismic data were interpreted in the Charisma module of the Geoframe software package. Using these interpreted seismic data, it is possible to reverse the tectonic movements to estimate the pa- leotopography before deposition of the Rijn Member.

\section{Seismic interpretation}

The seismic survey that was used for this interpretation was shot in 1989 and includes 520 in-lines and 550 cross-lines, with a line spacing of 25 and 12.5
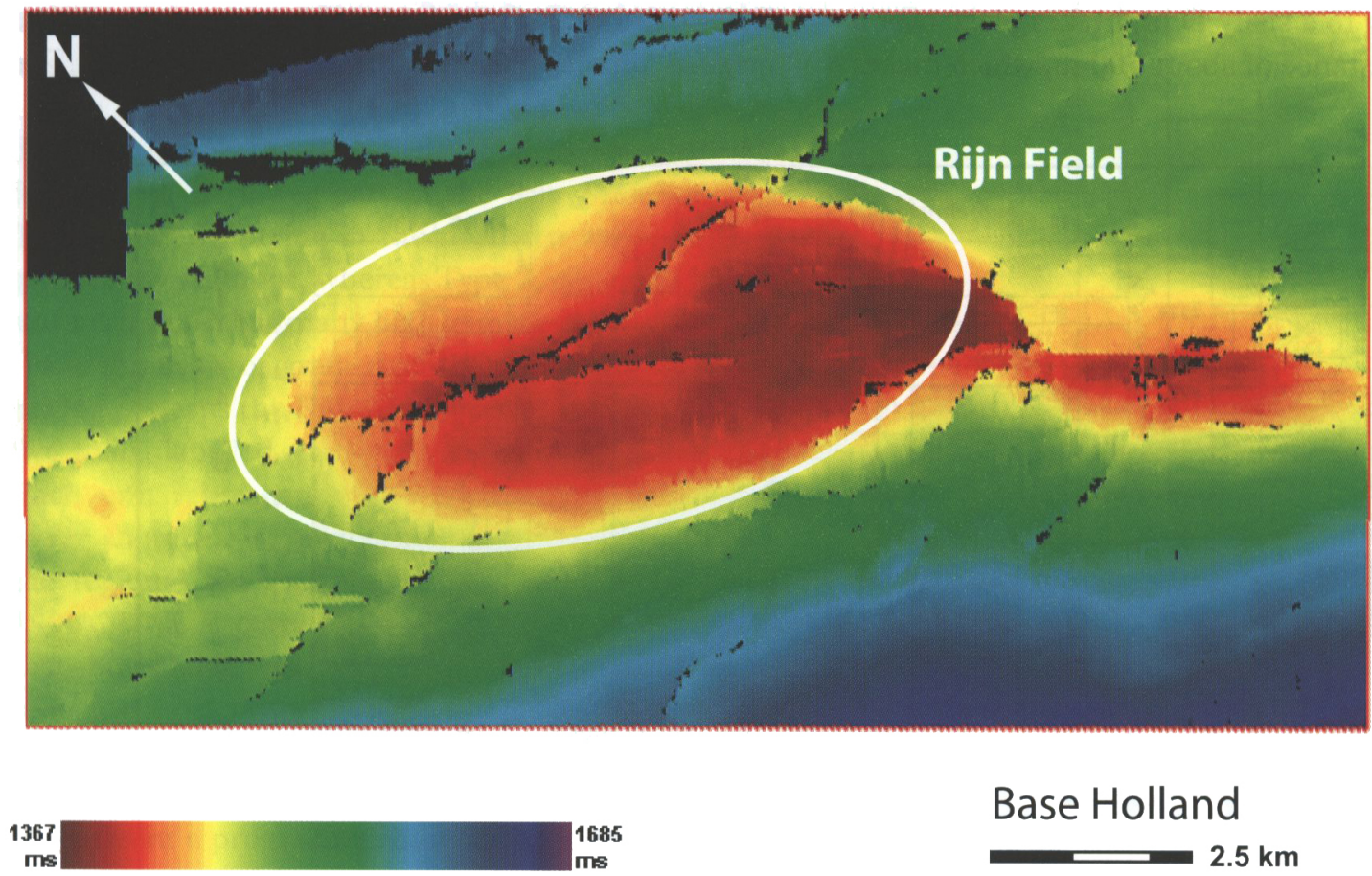

Base Holland

$2.5 \mathrm{~km}$
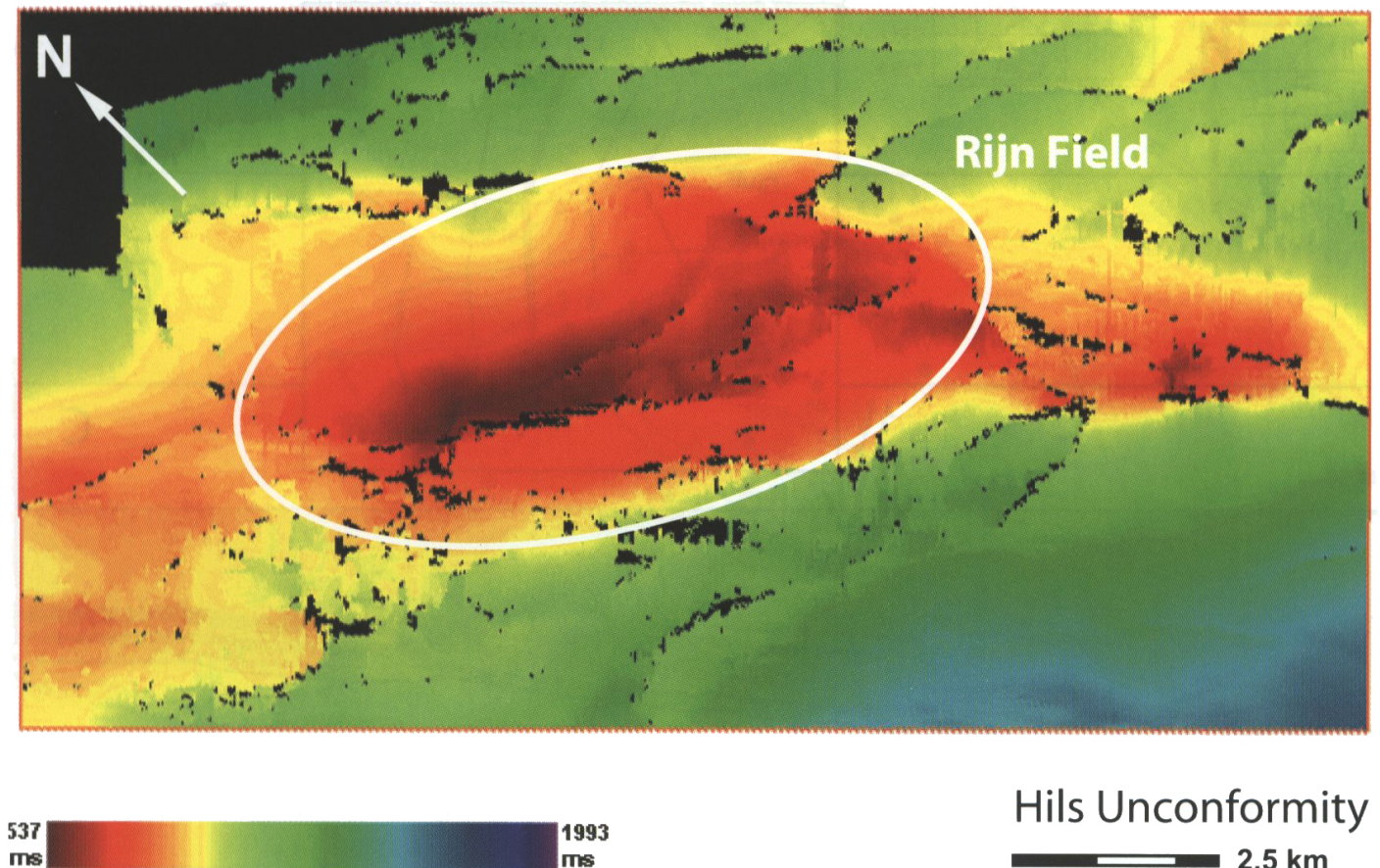

Fig. 6. Interpreted time-maps of the Base Holland and the Hils Unconformity in the P15-block. The colours are indicative for the depth of the horizon. Red colours represent high areas, while blue colours are low areas. The black colour denotes areas where the surface could not be interpreted due to missing data or lack of amplitude differences. The white line encircles the location of the Rijn Field. 
Fig. 7. The base-map of the Rijn Field showing the location of the wells, and indicating the boundaries of the seismic survey. The faults were retrieved from fault interpretation.

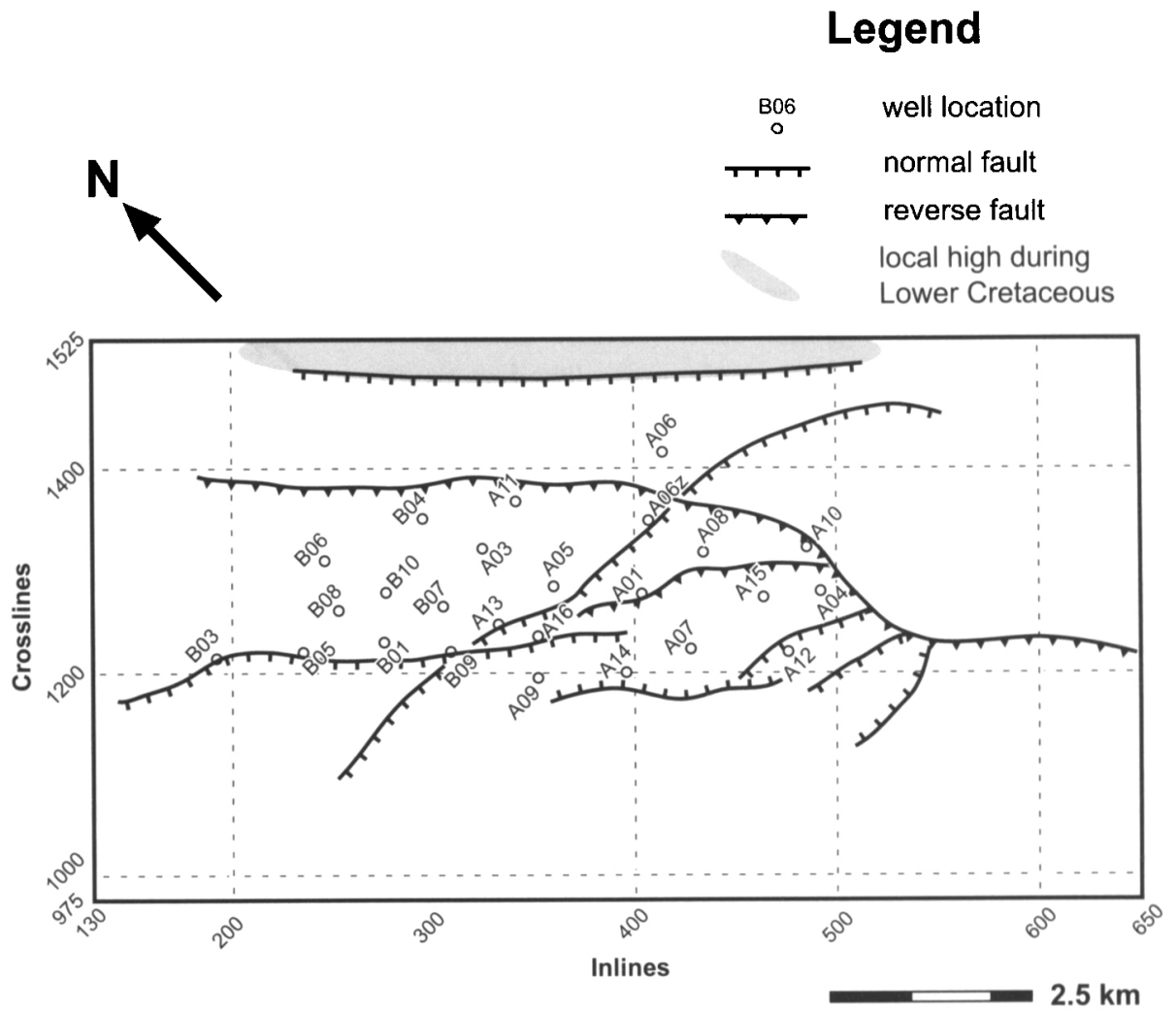

meters, respectively, which covers an area of approximately $13-\mathrm{km}$ by $7 \mathrm{~km}$. The seismic data set holds much information on the geological history of the area.

Fig. 6 shows the interpreted time-maps of the horizons that represent the base of the Holland Formation ('Base Holland') and the 'Hils Unconformity'. Although the maps present the two-way travel time of the seismic signal and do not show the exact depth, they give a good indication of the structural appearance the Rijn Field. Two distinct features can be derived from the time-maps. The most apparent feature that can be recognised on the time-maps is the anticlinal structure of the Rijn Field, which resulted from the compressional phases during the Late Cretaceous and Early Tertiary. In combination with the fault interpretation it can be concluded that the anticline developed in a complex wrench-fault system on the upthrown block of the reverse fault (see Fig. 7).

This wrench-fault-associated deformation is also present elsewhere in the Mesozoic basins (Dronkers \& Mrozek, 1991; Racero-Baena \& Drake, 1996). Secondly, when comparing the horizons of the Base Holland and the Hils Unconformity it is obvious that the basement of the Rijn Member is a discontinuous surface with many irregularities. The rugged paleotopography is a result of partial truncation of the tilted fault blocks which were exposed to the surface after the Mid Kimmerian uplift. This high degree of relief is thought to have caused the large variations in thickness in the Rijn Member. While locally deeper areas were filled in, somewhat higher areas were not drowned immediately or remained longer in the active beach zone with the result that less material was preserved there. Syn-sedimentary tectonics may have caused even larger thickness variations. A similar relationship between sandstone thickness and paleotopography has been observed in the Rijswijk Member (Racero-Baena \& Drake, 1996).

\section{Paleotopography}

Since it is clear that the paleotopography must have had a large influence on sedimentation in this area, it was decided to examine the seismic sections in more detail. To reconstruct the paleo-environment at the time of deposition of the Rijn Member, several seismic lines were flattened along a horizon in the Vlieland Claystone Formation a little above the top of the Rijn Member. In this way the post-Vlieland structural component of the geological history of the Rijn Field is removed. Fig. 8 shows a NE-SW section derived from such a flattened seismic in-line. It is considered a rough approximation of how the geological structure must have been during the Early Cretaceous and it supports the theory that the thickness differences in the Rijn Member are caused by the rugged paleotopography. The seismic detail of Fig. 8 

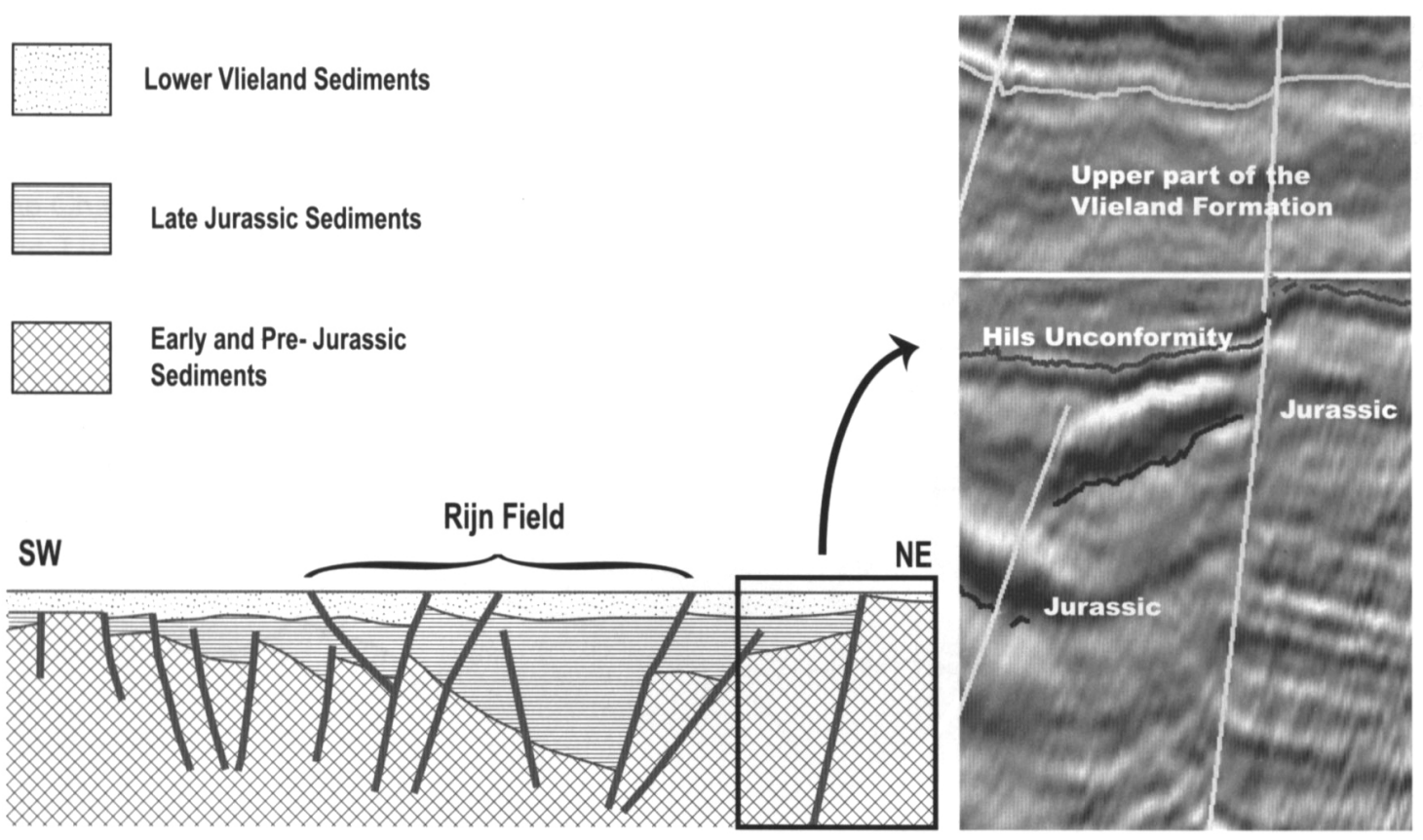

Fig. 8. A seismic detail shows proof of non-deposition during the sedimentation of the Rijn Member. The position of this detail with respect to the Rijn Field is shown in the flattened section. The boundary between the Late Jurassic sediments and the Lower Vlieland sediments is indicative of the paleotopography during the deposition of the Rijn Member.

shows that at this location there is even a hiatus north of the fault. This implies that during the deposition of the Rijn Member this fault block was above sea level and acted as the coastline. This hiatus was mapped and the mainland appeared to extend in a NW-SE direction along the northeastern edge of the base-map (Fig. 7). This high is most likely connected to the Winterton Foothills, a southeastern extension of the Winterton High to the west of the Rijn Field.

The existence of this high to the north of the Rijn Field has a large impact on the depositional model of the environment. While the presence of the London Brabant Massif to the Southwest might initially suggest a marine influence from the Northeast, the peninsula sheltered the Rijn area from the north with the marine influence coming from the south. This is in contrast with most other Lower Cretaceous shallow marine systems on the southern margins of the West Netherlands Basin (Den Hartog Jager, 1996).

\section{Stratigraphic model of the Rijn Member}

An impression of the depositional model is presented in Fig. 9, which summarises the sedimentary history of the environment of the Rijn Field. This model is derived from the gamma-ray logs.

Fig. 9a is based on seismic fault interpretation and shows the transtensional structure of the basement rock, which exists of several tilted fault blocks that were created during the rifting event. Partial infill

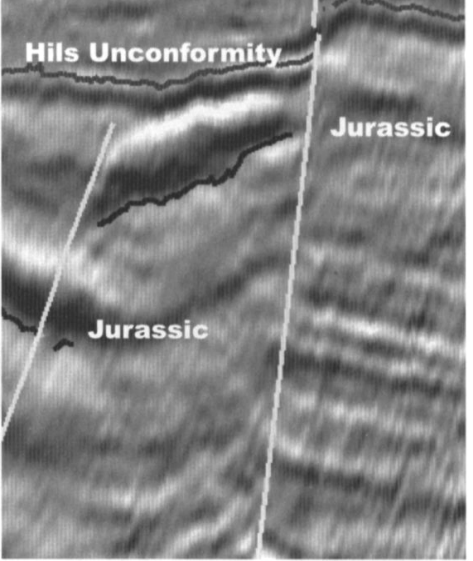

A

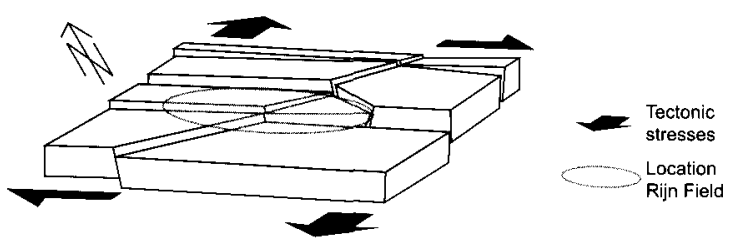

B

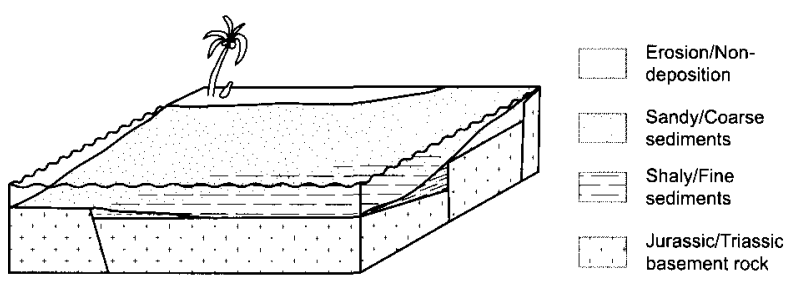

C

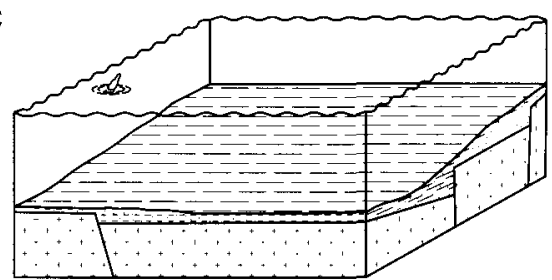

D

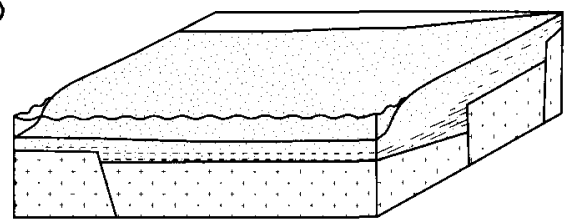

Fig. 9. A: A 3-D sketch of the fault pattern of the basement of the Rijn Member. The arrows indicate the direction of the tensional forces that created the faults. B, C and D:Three intervals of the deposition of the Rijn Member (see text for details). 
with Delfland deposits and truncation of the tops of the blocks smoothed the landscape somewhat, before the sea entered in the West Netherlands Basin. The first period of sedimentation of the Rijn Member is shown in Fig. 9b. The rate of sea-level rise was decreasing gradually and the sea level may eventually have fluctuated to cause deposition of clean shoreface sands and possibly barrier islands in the northern higher parts and an alternating succession of sand layers and shale layers towards the lower southern parts. The northernmost block is thought to have been above sea level most of the time during this transgressive period. The only exception to this may have been during the highstand, when a field-wide shale layer was deposited (see Fig. 9c). After maximum flooding the sedimentary environment was dominated by progradation of a barrier complex, indicated by the coarsening upward profiles in the wells (see Figs 4 and $7 \mathrm{a}$ for examples). A normal lateral grain-size distribution associated with these barrier-island and strand-plain systems is expected along the northsouth profile (Davis Jr., 1978; Reinson, 1984), although a distinct step-wise segmentation of average grain sizes could exist due to the structural offset of the different blocks (Fig. 9d). Sedimentation of the Rijn Member ends after the deposition of a thin fieldwide sand layer of constant thickness (about 5 meters), before the area completely drowned It is believed that this layer is a transgressive sheet sand resulting from reworking of the barrier sands.

A general estimation of sea level movements can be derived from this depositional model, which we need for application of process-response simulations to the Rijn Member.

\section{Process-response simulations of the Rijn Member}

The process-response model of Storms (2002) was used for evaluation of our depositional model of the
Rijn Member. The program, named BARSIM, simulates the geological processes in wave-dominated coastal environments on geological time scales, and builds a 2-dimensional sequence stratigraphic profile.

The model starts with an initial profile. Sedimentation and erosion take place controlled by a wave regime, under the influence of storms. During highmagnitude storms, wave energy causes major sediment redistribution along the profile, while during fair-weather conditions sediment redistribution will be minor. Additionally, sediment can be supplied to or removed from the system. Combined with the sealevel fluctuations the system responds accordingly to create a dynamic equilibrium between erosion, deposition and the simulated profile.

There are many input parameters that can be varied, but the most important parameters include the offshore slope, the sea-level curve, and the sediment supply curve through time. Other input parameters mainly influence the wave regime and the sediment characteristics and these were calibrated to modern coastal environments.

To estimate the relative sea level curve we used the stratigraphic sequence derived from the well logs. The sediment distribution in the Rijn Member indicates that the overall ongoing sea level rise during the Late Jurassic and Early Cretaceous has been subject to lower order fluctuations which caused temporary stillstands or even small-scale sea level falls. This is in agreement with trends found in literature (Haq et al., 1988; Den Hartog Jager, 1996). The general succession of a large period of transgression, a short period of regression, again followed by transgression - which eventually drowned the entire complex - was maintained for input in BARSIM.

The topography that was derived from seismics was reduced to a gentle slope with three major fault offsets to represent the tilted fault blocks.

The sediment supply curve is not easily retrieved from field data. A low sediment supply was assumed

Table 1. The input parameters of BARSIM, which were varied for the different scenarios in Fig. 10. (Btu stands for BARSim time units; for the Rijn Field these correspond to approximately $10 \mathrm{yrs}$.)

\begin{tabular}{lllll}
\hline Scenario & Fig. 10-A & Fig. 10-B & Fig. 10-C & Fig 10-D \\
\hline End Time (Btu) & 120,000 & 120,000 & 120,000 & 120,000 \\
Paleotopography & Tilted Faultblocks & Gentle slope & Tilted Faultblocks & Tilted Faultblocks \\
Sea level Osc. Period (Btu) & 150,000 & 150,000 & 150,000 & 300,000 \\
Sea level Osc. Phase & 1.9 & 1.9 & 1.9 & 1.5 \\
Sea level Osc. Amplitude (m) & 20 & 20 & 20 & 10 \\
Periodic Sea Level Rise (m) & 40 & 40 & 40 & 40 \\
Sediment Supply Osc. Period (Btu) & 130,000 & 130,000 & - & 130,000 \\
Sed Supply Osc. Phase & 0.8 & 0.8 & 6 & 6.8 \\
Mean Sed Supply (m $/$ Btu) & 6 & 6 & - & 6 \\
Sed Supply Osc. Amplitude $\left(\mathrm{m}^{2} / \mathrm{Btu}\right)$ & 6 & 6 & - & 6 \\
\hline
\end{tabular}


with small fluctuations, which were adjusted to achieve a better match.

Fig. 10 presents a realisation of the process-response simulator that reflects the architecture of the Rijn Member and shows the effects of the most important input parameters. The values of the parameters that were varied during the simulations are summarised in Table 1.
The grain-size profile in Fig. 10-A shows the same succession of sedimentary sequences as those described in the previous section. While this realisation of the process-response simulator looks satisfactory, we are aware that model assumptions and limitations do not allow the construction of a perfect description of the depositional behaviour (Lessenger \& Lerche, 1999). For instance, the model does not consider the
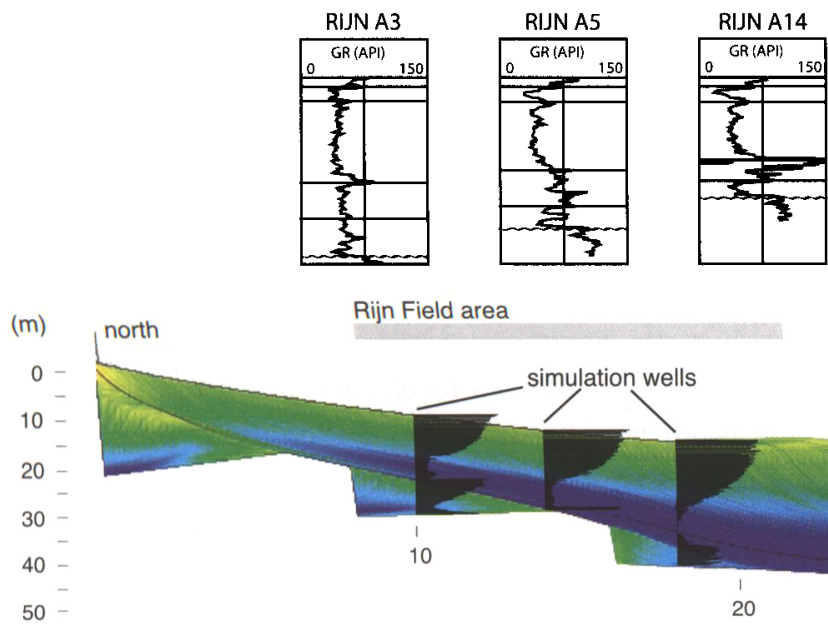

Rijn Field area

(a)
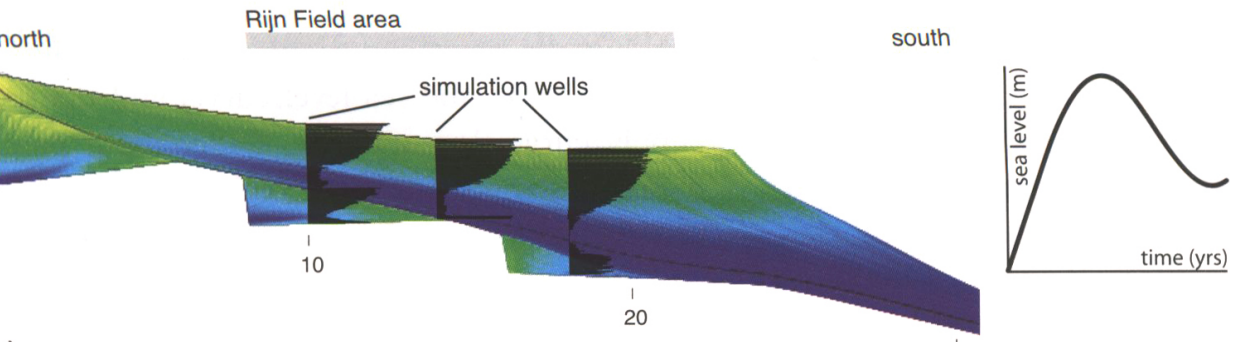

30

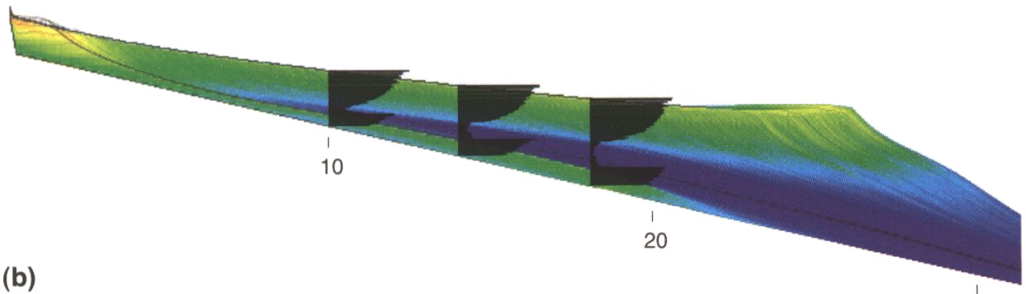

30

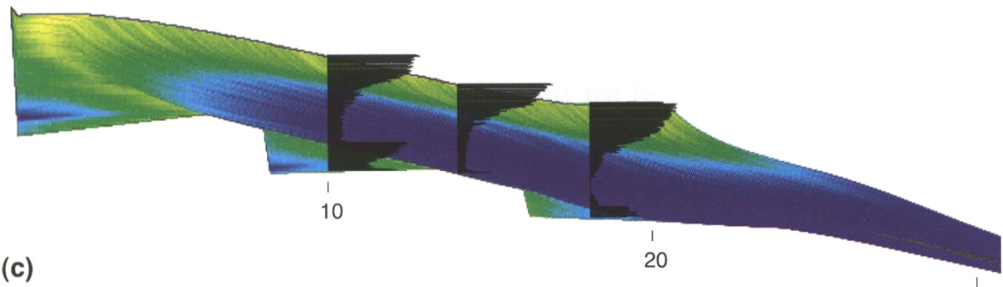

30

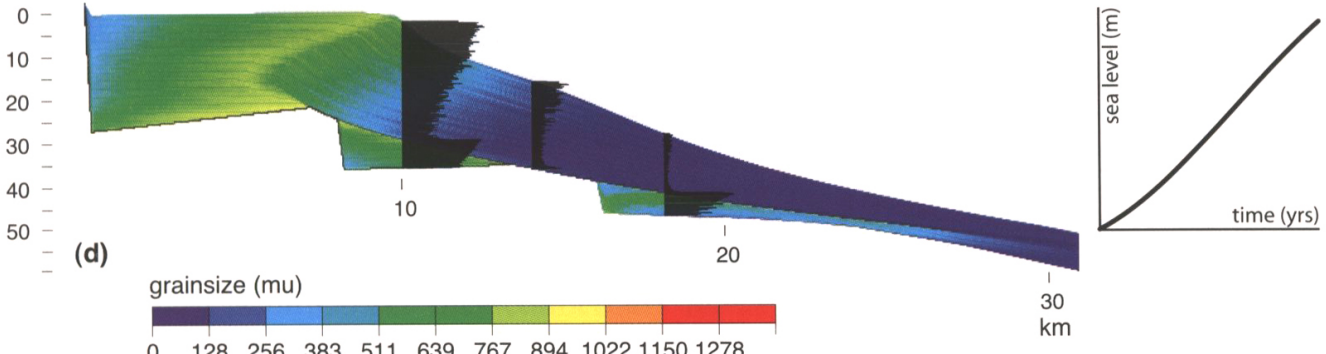

$\begin{array}{lllllllll}0 & 128 & 256 & 383 & 511 & 639 & 767 & 894 & 102211501278\end{array}$

Fig. 10. The output of the process-response simulator presented in grain-size profiles for 4 different simulation runs. Vertical scale is in metres, horizontal scale in kilometres. The gray bar on top indicates the corresponding location of the Rijn Field. Simulated well logs are drawn in each simulation showing the mean grain size (coarse material - high readings). Three gamma-ray well logs are shown on top for reference. (a) The best-fit scenario, obtained with the sea level curve shown at the right, a faulted topography and a fluctuating sediment supply; (b) same scenario as the best-fit scenario, only without a faulted topography; (c) best-fit scenario with steady sediment supply; (d) alternate scenario based on a continuous rising sea level. 
effects of compaction and loading. As a result there may be an overestimation of the thickness of fine material and an underestimation of the available accommodation space, which could explain the limited overall thickness of the modelled stratigraphy. Another limitation of the model involves the erosion of hard rock material, which may have resulted in the near absence of sandy sediments in the lower parts of the central simulated wells of Fig. 10. From the simulation shown in Fig. 10-B, where the pre-existing topography is not used, it is obvious that the paleotopography must have had a large influence on the Rijn Member. Especially in the northern part of the Rijn Field the member is much thicker in the lower units than what could be modelled using a gentle slope.

As was mentioned before, it is often very difficult to derive the amounts of sediment supplied to the system through time. Although its influence on the system may seem smaller than sea level fluctuations or basement topography, Fig. 10-C illustrates that it has at least some impact, predominantly on the thickness of individual sequences.

Another well-known problem during inversion of a forward model is non-uniqueness, which means that several sets of parameters may satisfy the data (Lessenger $\&$ Lerche, 1999). This does still leave room for variations in our suggested scenario or might even imply the validity of a completely different scenario.

As an example of an alternate scenario for the Rijn Field one could pose based on sedimentology, that since all preserved sands are medium- to very finegrained, and the well-logs in the upper units correlate very well, we are dealing here with an aggradational system of lower shoreface sands. Fig. 10-D shows an attempt to simulate this scenario, which illustrates that it is hardly possible to deposit these lower shoreface sands over an extent of more than 5 kilometres. While this could be the result of inability to find the correct combination of parameters, or due to limitations of the model, it motivates our preference for the first scenario. As a consequence, it would be expected that the presence of clinoforms (as in Fig. 10A) should also be observed in the cores and the wireline logs (Wehr \& Brasher, 1996). However, due to the extensive bioturbation these sedimentary structures can no longer be recognised.

From the results it is evident that our depositional model for the Rijn Field is supported by a numerical model based on geological principles. While many more plausible realisations could be constructed with the program by slightly changing the input parameters, the general concept of deposition of the member remains the same. Application of the model thus provides a deeper understanding of the sedimentary his- tory and the distribution of reservoir properties that can be derived from the grain size profile. This could eventually be translated into a more realistic interpolation than what could be obtained by geostatistical interpolation between wells.

\section{Conclusions}

In order to provide an example of application of a numerical simulation model to a subsurface reservoir the geology of the Lower Cretaceous Rijn Field was investigated The interpretation of well data and seismic data led to the definition of a depositional model that includes the structural setting and the sedimentary history of the Rijn Member. Recognition of a hiatus to the north of the Rijn Field indicates subaerial exposure -possibly a peninsula- during the deposition of the Rijn Member.

The depositional model presents the succession of a transgressive systems tract and a highstand systems tract, before the entire area was drowned From this model a representative sea level curve was constructed, which was used for the process-response simulations.

The numerical process-response model BARSIM was successfully applied to the Rijn Field. A scenario was derived from the depositional model, which resulted in a north-south grain-size profile that corresponds very well to the gamma-ray measurements along a north-south section through the Rijn Member. Discrepancies between the simulated logs and the measured logs can be related to the limitations of the numerical model and the incompletely known input parameters. Alternate scenarios may still be valid, but the simulation runs can also be used to decline other hypothetical scenarios.

While inversion remains a tedious task, the results have proven that numerical simulations of geological processes can indeed supply added value on heterogeneous distribution of reservoir properties.

\section{Acknowledgements}

This study would not have been possible without all data, which were kindly provided by BP Nederland Energie B.V and the partners Clyde Petroleum Exploratie B.V., DSM Energie B.V., Dyas B.V., Dyas Nederland B.V., Oranje-Nassau Energie B.V., Van Dyke Netherlands Inc., Veba Oil Nederland Aardgas B.V. and Veba Oil and Gas Netherlands B.V.

Many thanks go out especially towards W.J.S. van Soest of BP for his effort. E.J.T. Duijn and S. Tigrek are acknowledged for their assistance during seismic interpretation. The work and discussions of F.P.A. 
Maartense were very useful and were much appreciated J.E.A. Storms is appreciated for his valuable comments on the process-response simulations.

G.J. Weltje and C. Van Der Zwan are appreciated for their comments on the manuscript, which helped to improve this paper considerably.

\section{References}

Bodenhausen, J.W.A. \& Ott, W.F., 1981. Habitat of the Rijswijk Oil Province, onshore, The Netherlands. In: Illing, L.V. \& Hobson, G.D. (Eds): Petroleum Geology of the Continental Shelf of North-West Europe. Heyden (London): 301-309.

Davis Jr., R.A., 1978. Barrier island systems - a geologic overview. In: Davis Jr., R.A. (Ed.): Coastal sedimentary environments. Springer Verlag (New York): 1-46.

De Jager, J., Doyle, M.A., Grantham, P.J. \& Mabillard, J.E., 1996. Hydrocarbon habitat of the West Netherlands Basin. In: Rondeel, H.E., Batjes, D.A.J. \& Nieuwenhuijs, W.H. (Eds): Geology of gas and oil under the Netherlands. Royal Geological and Mining Society of the Netherlands (KNGMG) / Kluwer Academic Publishers (Dordrecht): 191-209.

Den Hartog Jager, D., 1996. Fluviomarine sequences in the Lower Cretaceous of the West Netherlands Basin: Correlation and seismic expression. In: Rondeel, H.E., Batjes, D.A.J. \& Nieuwenhuijs, W.H. (Eds): Geology of gas and oil under the Netherlands. Royal Geological and Mining Society of the Netherlands (KNGMG) / Kluwer Academic Publishers (Dordrecht): 229-241.

Dromgoole, P. \& Speers, R., 1997. Geoscore: a method for quantifying uncertainty in field reserve estimates. Petroleum Geoscience 3: 1-12.

Dronkers, A.J. \& Mrozek, F.J., 1991. Inverted basins of the Netherlands. First Break 9: 409-425.

Dubrule, O. \& Damsleth, E., 2001. Achievements and challenges in petroleum geostatistics. Petroleum Geoscience 7: 1-7.

Goh, L.S., 1996. The Logger oil Field (Netherlands offshore): reservoir architecture and heterogeneity. In: Rondeel, H.E., Batjes, D.A.J. \& Nieuwenhuijs, W.H. (Eds): Geology of gas and oil under the Netherlands. Royal Geological and Mining Society of the Netherlands (KNGMG) / Kluwer Academic Publishers (Dordrecht): 255-263.

Granjeon, D. \& Joseph, P., 1999. Concepts and applications of a 3D multiple lithology, diffusive model in stratigraphic modeling. In: Harbaugh, J.W., Watney, W.L., Rankey, E.C., Slingerland, R., Goldstein, R.H. \& Franseen, E.K. (Eds): Numerical experiments in stratigraphy; recent advances in stratigraphic and sedimentologic computer simulations. SEPM Spec. Publ. 62, (Tulsa, OK, USA): 3-21.

Gras, R. \& Geluk, M.C., 1999. Late Cretaceous-Early Tertiary sedimentation and tectonic inversion in the southern Netherlands. Geologie en Mijnbouw 78: 1-19.

Haq, B.U., Hardenbol, J. \& Vail, P.R., 1988. Mesozoic and Cenozoic chronostratigraphy and cycles of sea-level change. In: Wilgus, C.K., Posamentier, H., Roos, C.A., \& Kendall, C. (Eds): Sea-level changes - an integrated approach. SEPM Special Publication 42: 71-108.

Lessenger, M. \& Lerche, I., 1999. Inverse modeling. In: Harbaugh, J.W., Watney, W.L., Rankey, E.C., Slingerland, R., Goldstein, R.H. \& Franseen, E.K. (Eds): Numerical experiments in statigraphy; recent advances in stratigraphic and sedimentologic computer simulations. SEPM Spec. Publ. 62, (Tulsa, OK, USA): 29-31.

Maartense, F.P.A., 1999. Detailed analysis of the Lower Creta- ceous sedimentary environment of the Rijn Field. Unpublished MSc. Thesis, Delft University of Technology (Delft): $79 \mathrm{pp}$

Pemberton, S.G., Van Wagoner, J.C. \& Wach, G.D., (1992). Ichnofacies of a wave-dominated shoreline. In: Applications of Ichnology to Petroleum Exploration, SEPM Core Workshop No. 17, SEPM, (Tulsa, Ok, USA): 382 pp.

Racero-Baena, A. \& Drake, S.J., 1996. Structural style and reservoir development in the West Netherlands oil province. In: Rondeel, H.E., Batjes, D.A.J. \& Nieuwenhuijs, W.H. (Eds): Geology of gas and oil under the Netherlands. Royal Geological and Mining Society of the Netherlands (KNGMG) / Kluwer Academic Publishers (Dordrecht): 191-209.

Reinson, G.E., 1984. 'Barrier-island and associated strand-plain systems'. In: Walker, R.G. (Ed.): Facies models, second edition. Geological Association of Canada Publications (Toronto, Ontario): 119-140.

Storms, J.E.A., 2002. Controls on shallow-marine stratigraphy: a process-response approach. Ph.D. thesis Delft University of Technology (Delft): $151 \mathrm{pp}$

Storms, J.E.A., Weltje, G.J., Van Dijke, J.J., Geel, C.R. \& Kroonenberg, S.B., 2002. Process-response modelling of wave-dominated coastal systems: simulating evolution and stratigraphy on geological timescales. Journal of Sedimentary Research 72: 226-239.

Syvitski, J.P.M., \& Hutton, E.W.H., 2001. 2-D SEDFLUX 1.0C: an advanced process-response numerical model for the fill of marine sedimentary basins. Computers \& Geosciences 27: 731753.

Tetzlaff, D. \& Pride, G., 2001. Sedimentary process modeling: from academia to industry. In: Merriam, D.F. \& Davis, J.C. (Eds): Geological modeling and simulation: sedimentary systems. Computer applications in the earth sciences. Kluwer Academic Publishers (MA, USA): 45-70.

Van Adrichem Boogaert, H.A. \& Kouwe, W.F.P., 1993. Stratigraphic nomenclature of The Netherlands; revision and update by RGD and NOPEGA. Mededelingen Rijks Geologische Dienst 50 (Haarlem).

Van Wijhe, D.H., 1987. Structural evolution of inverted basins in the Dutch offshore. In: Ziegler, P.A. (Ed.): Compressional IntraPlate Deformations in the Alpine Foreland. Tectonophysics 137: 171-219.

Watney, W.L., Rankey, E.C. \& Harbaugh, J., 1999. Perspectives on stratigraphic simulation models: current approaches and future opportunities. In: Harbaugh, J.W., Watney, W.L., Rankey, E.C., Slingerland, R., Goldstein, R.H. \& Franseen, E.K. (Eds): Numerical experiments in statigraphy; recent advances in stratigraphic and sedimentologic computer simulations. SEPM Spec. Publ. 62, (Tulsa, OK, USA): 3-21.

Wehr, F.L. \& Brasher, L.D., 1996. Impact of sequence-based correlation style on reservoir model behaviour, lower Brent Group, North Cormorant Field, UK North Sea. In: Howell, J.A. \& Aitken, J.F. (Eds): High resolution sequence stratigraphy: Innovations and applications. Geological Society Special Publication No 104: 115-128.

Ziegler, P.A., 1982. Geological atlas of Western and Central Europe. Elsevier (Amsterdam): $130 \mathrm{pp}$. 